\title{
PEMIKIRAN FILOSOFIS TENTANG MASYARAKAT
}

\author{
Sapirin \\ Madrasah Ibtidaiyah Negeri 2 Pinangsori Tapanuli Tengah \\ JIn. Jenderal Ahmad Yani Pinang Sori Tapanuli Tengah \\ sapirinn@yahoo.com
}

\begin{abstract}
Abstrak
Tulisan ini bertujuan untuk mendeskripsikan pemikiran filosofis tentang masyarakat. Manusia hidup tidak bisa dipisahkan dengan masyarakat dan masyarakat tidak pernah ada jika kelompok manusia tidak mendiami didalamnya. Manusia dan masyarakat seakan bagaikan dua sisi mata uang yang tidak bisa dipisahkan. Jika salah satunya dipisahkan, maka akan melahirkan kepalsuan yang tidak laku dalam penggunaannya. Masyarakat tanpa manusia tidak bisa menghasilkan apa-apa dan manusia tanpa masyarakat, maka tidak ada tempat sebagai panggung publikasi.
\end{abstract}

\section{Abstract}

This paper aims to describe philosophical thinking about society. Humans live cannot be separated from society and society has never existed, if human groups do not inhabit it. Man and society seem to be like two sides of a coin that cannot be separated. If one of them is separated, it will give birth to falsehood that is not sold in its use. Communities without humans cannot produce anything and people without society there is no place as a stage for publication.

Kata Kunci: Pemikiran, Filosofis, dan Masyarakat 


\section{Pendahuluan}

Sebagai makhluk sosial, hidup bermasyarakat adalah perkara yang tidak dapat kita hindari dalam kehidupan ini.Tentu dengan segala konsekwensi yang terdapat di dalamnya.Adanya berbagai problem dalam kehidupan bermasyarakat bukan merupakan alasan bagi seseorang untuk menghindar, lalu menarik diri untuk bergaul di tengah masyarakatnya.Selain hal tersebut dapat dikategorikan sebagai tindakan yang mengabaikan kebutuhan fitrah manusia, sifat tersebut juga boleh dikatakan sebagai bentuk pelarian dari tanggung jawab.

Keinginan untuk mewujudkan lingkungan yang demikian itu mendorong perlunya membina masyarakat yang berpendidikan, beriman, dan bertaqwa kepada Tuhan. Karena di dalam masyarakat yang demikian itulah akan tercipta lingkungan dimana berbagai aturan dan perundangundangan dapat ditegakkan. Emil Durkheim berpendapat bahwa "ide tentang masyarakat adalah jiwa agama", artinya, jiwa daripada agama adalah pembentukan masyarakat itu sendiri, sehingga mencita-citakan "masyarakat" adalah sejalan dengan gagasan agama itu sendiri. ${ }^{1}$ Al-Quran sebagai sumber ajaran Islam telah memberikan perhatian yang besar terhadap perlunya pembinaan masyarakat.

\section{Pegertian Masyarakat}

Istilah masyarakat berasal dari kata musyarak yang berasal dari Bahasa Arab yang memiliki arti ikut serta atau berpartisipasi. ${ }^{2}$ Sedangkan dalam bahasa Inggris disebut Society. ${ }^{3}$ Masyarakat adalah sejumlah atau sekelompok manusia dalam wilayah tertentu yang mempunyai dasar atau pandangan hidup serta budaya. ${ }^{4}$ Dalam Kamus Besar Bahasa Indonesia masyarakat terdiri dari empat suku kata yaitu ma.sya.ra.kat yang memiliki

'Durkheim, Emil, The Elementary Forms of the Religious Life (trans, Joseph Ward Swaim) (New York: Macmillan Company, 1915). HIm. 419

${ }^{2}$ Ibrahim, M. Katsir, Kamus Arab Indonesia -Indonesia Arab (Surabaya: Apollo,TT). HIm. 618

${ }^{3} \mathrm{http}: / /$ carapedia.com/pengertian_definisi_masyarakat_menurut_para_ahli_info488. html

${ }^{4}$ Chaniago, Amran YS, Kamus Lengkap Bahasa Indonesia (Bandung: Pustaka Setia, 2002) Cet. Ke V, HIm. 385 
arti sejumlah manusia dalam arti seluas-luasnya dan terikat oleh suatu kebudayaan yang mereka anggap sama. ${ }^{5}$

Menurut Al-Syaibani, Masyarakat adalah individu dan kelompok yang diikat oleh kesatuan Negara, kebudayaan dan agama. Termasuk jalinan hubungan timbal balik, kepentingan bersama, adat kebiasaan, polapola, teknik-teknik, sistem hidup, undang-undang, institusi dan segala segi dan fenomena yang dirangkum oleh masyarakat dalam pengertian yang luas dan baru. ${ }^{6}$

Hammudah Abdalati mendefinisikan masyarakat sebagai, suatu kelompok yang mencakup/meliputi dua karakter tertentu:

1. Kelompok yang didalamnya terdapat individu-individu yang dapat memiliki sebagian besar kegiatan dan berbagai pengalaman yang sangat berguna baginya.

2. Kelompok dimana orang yag berada didalamnya terikat oleh tanggung jawab dan oleh identitas bersama. ${ }^{7}$

Dan H. Abu Ahmadi mendefenisikan bahwa masyarakat adalah golongan besar atau kecil dari beberapa manusia, yang dengan sendirinya bertalian secara golongan dan mempunyai pengaruh satu sama lain. ${ }^{8}$

Masyarakat terdiri atas kelompok-kelompok manusia yang saling terkait oleh sistem-sistem, adat istiadat, serta hukum-hukum khas, dan yang hidup bersama. Kehidupan bersama ialah kehidupan yang di dalamnya kelompok-kelompok manusia hidup bersama-sama di suatu wilayah tertentu dan sama-sama berbagi iklim serta makanan yang sama. Pepohonan di suatu taman juga 'hidup' bersama dan sama-sama mendapatkan iklim serta makanan yang sama, seperti itu pula sekawanan rusa juga makan dan berpindah-pindah tempat bersama-sama. Namun, baik pepohonan maupun sekawanan rusa tak dapat dikatakan sebagai hidup bermasyarakat, karena mereka bukanlah masyarakat.

Dari pengertian di atas memberikan pemahaman, bahwa sebenarnya kehidupan manusia itu bersifat kemasyarakatan, secara fitrah manusia bersifat kemasyarakatan. Di satu pihak, kebutuhan, keuntungan,

${ }^{5}$ Tim Penyusun, Kamus Besar Bahasa Indonesia, Edisi ketiga (Jakarta: Balai Pustaka, 2005). HIm. 721

${ }^{6}$ Al-Toumy Al-Syaibani, Omar Mohammad, Falsafah Pendidikan Islam (Jakarta, Bulan Bintang:1979). hlm. 164.

${ }^{7}$ Qordhawi, Yusuf, Masyarakat Berbasis Syari'at Islam. terj. Abdus Salam Masykur (Solo: Intermedia, 2003). Jilid: 1. hlm. 11-12.

${ }^{8}$ Abu Ahmadi,Sosiologi Pendidikan (Jakarta: Rineka Cipta. 2004). hlm. 29. 
kepuasan, karya dan kegiatan manusia pada hakekatnya, bersifat kemasyarakatan, dan sistem kemasyarakatan akan tetap ada selama ada pembagian kerja atau aturan, dan rasa saling membutuhkan dalam suatu perangkat tertentu, tradisi dan sistem. Di pihak lain, gagasan-gagasan, ideal-ideal, perangai-perangai, suatu kebiasaan-kebiasaan khas menguasai manusia umumnya, dengan memberi mereka suatu rasa kesatuan.

Dengan kata lain, masyarakat merupakan suatu kelompok manusia yang di bawah tekanan serangkaian kebutuhan dan di bawah pengaruh seperangkat kepercayaan, ideal dan tujuan, tersatukan dan terlebur dalam suatu rangkaian kesatuan kehidupan bersama. ${ }^{9}$

\section{Masyarakat dalam pandangan al-Qur'an dan penafsirannya}

Dalam Bahasa Arab ditemui kata "al-musyarakah" yang berarti "Perserikatan". Perserikatan sama dengan perkumpulan, ikatan, dan perhimpunan. Istilah ini memang sangat terkait dengan kemasyarakatan.Dalam al-Qur'an Ada banyak istilah yang berhubungan dengan "kemasyarakatan", penulis membatasinya pada kata-kata Ummah, Qaum, Qabilah, Syu'ub, Qoryah.

\section{Q.S Al-Baqarah: 213}

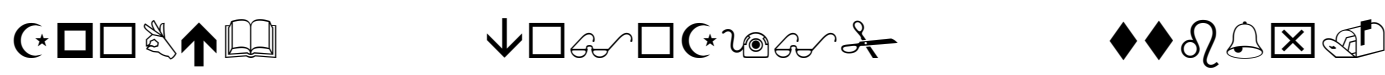

+ or of 囚 $\triangle \rightarrow \sim$

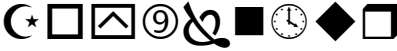

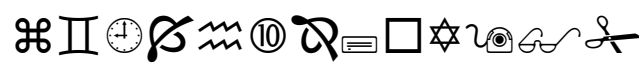

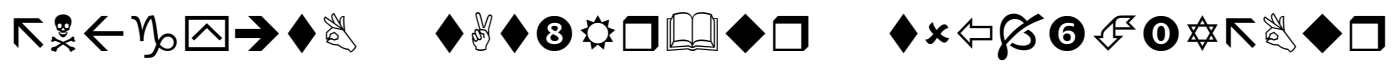

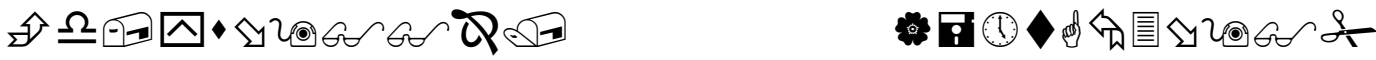

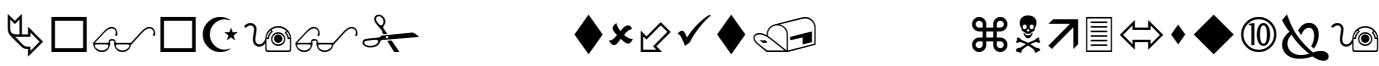

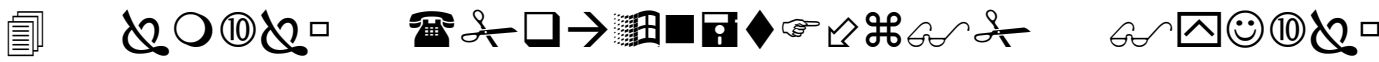

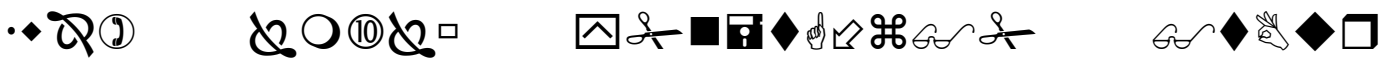

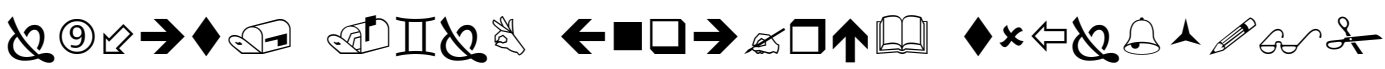

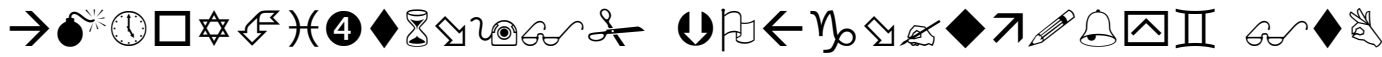

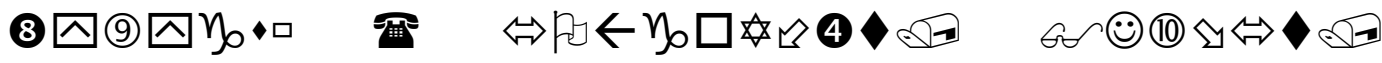

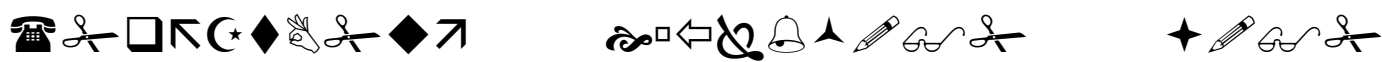

${ }^{9}$ Muthahhari, Murtadha, Masyarakat Dan Sejarah, terjemahan: M.Hashem, judul asli: Society and History (Bandung: Mizan, 1992). hlm. 15.

${ }^{10}$ Al Munawwir, Ahmad Warson, A/ Munawwir Kamus Arab-Indonesia (Surabaya: Pustaka Progresif 1984).HIm. 765. 


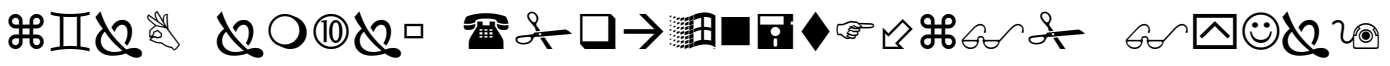

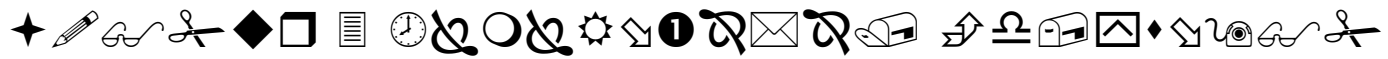

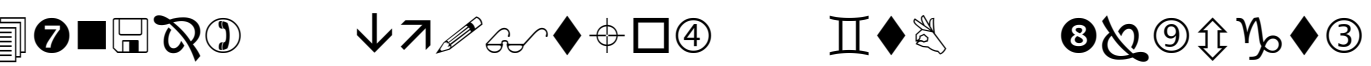

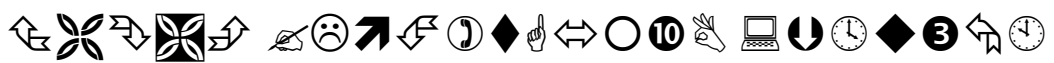

Artinya:

"Manusia itu adalah umat yang satu. (setelah timbul perselisihan), Maka Allah mengutus Para Nabi, sebagai pemberi peringatan, dan Allah menurunkan bersama mereka kitab yang benar, untuk memberi keputusan di antara manusia tentang perkara yang mereka perselisihkan. tidaklah berselisih tentang kitab itu melainkan orang yang telah didatangkan kepada mereka Kitab, Yaitu setelah datang kepada mereka keterangan-keterangan yang nyata, karena dengki antara mereka sendiri. Maka Allah memberi petunjuk orang-orang yang beriman kepada kebenaran tentang hal yang mereka perselisihkann itu dengan kehendak-Nya.dan Allah selalu memberi petunjuk orang yang dikehendaki-Nya kepada jalan yang lurus".

Al-Qur'an menyebutkan kata-kata ummah sebanyak 49 kali yang terdapat dalam 23 surat, sedangkan kata-kata umam sebanyak 11 kali, dalam 9 surat." Kata "Ummataw wahidah" dalam ayat ini berarti ummat yang satu, yaitu satumanhaj "jalan hidup" dan satu pandangan. Hal ini mengisyaratkan kepada sekelompok kecil manusia pertama yang berupa keluarga Adam dan Hawa dengan anak-anak cucunya, sebelum terjadinya perbedaan mengenai persepsi, pola pikir, pandangan hidup dan keyakinan mereka. Maka, al-Qur'an menetapkan bahwa asal muasal manusia itu satu. Mereka adalah anak keturunan dari keluarga pertama, keluarga Adam dan Hawa. Allah menghendaki menjadikan seluruh manusia ini produk dari sebuah keluarga yang kecil, untuk menetapkan prinsip kekeluargaan dalam kehidupan mereka, dan menjadikan keluarga sebagai fondasi pertama bangunan masyarakat. ${ }^{12}$

2. Q.S Ali Imran: 104

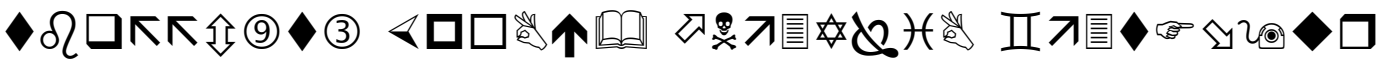

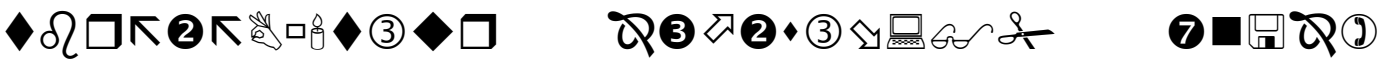

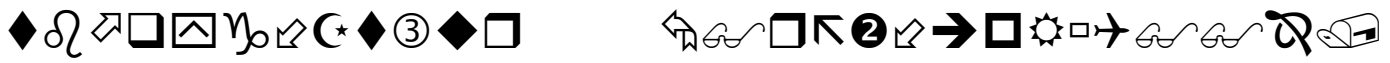

${ }^{11}$ Al Muna Baqy. Abdul Fuad Muhammad, Al-Mu'jam Li al-fazhi al-Qur'an al-Karim (Mesir; Daar al Kitab 1945). HIm. 30

${ }^{12}$ E-book, Tafsir fi zhilalil qur'an I. HIm. 256 


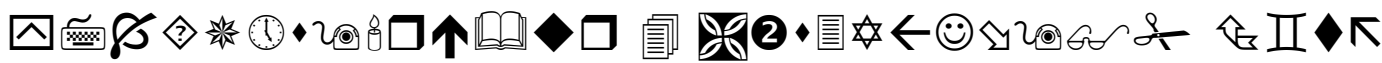

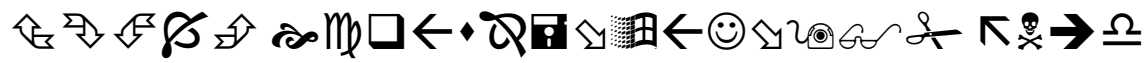

Artinya:

"Dan hendaklah ada di antara kamu segolongan umat yang menyeru kepada kebajikan, menyuruh kepada yang ma'ruf dan mencegah dari yang munkar, merekalah orang-orang yang beruntung".

Kata "Ummah" disini berarti segolongan ummat, ini merupakan perintah kepada sebahagian manusia untuk menyeru kepada kebaikan dan amar ma'ruf nahi munkar.Karena kata "Min" menunjukkan sebahagian, karena perintah ini merupakan fardu kifayah yang tidak mesti bagi seluruh ummat dan tidak pula layak bagi setiap orang. ${ }^{13}$

Menurut tafsir al-Maraghy, Ummah yang dimaksud dalam ayat ini adalah sekelompok tertentu dalam masyarakat, bisa berupa organisasi, pemerintah, atau Negara, sebagai bagian dari masyarakat.Oleh karena itu, dalam melaksanakan dakwah, wajib baginya memenuhi syarat-syarat agar dapat melaksanakan kewajibannya dengan sebaik-baiknya, dan bisa menjadi contoh saleh yang menjadi panutan dalam ilmu dan amalnya. ${ }^{14}$

3. Q.S Ali Imran: 110

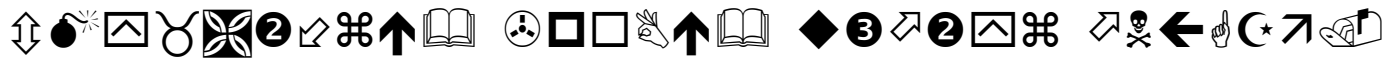

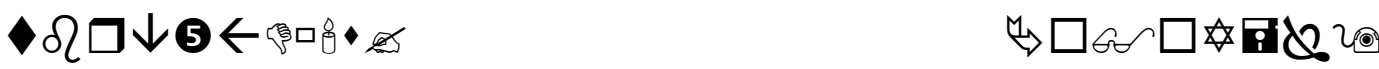

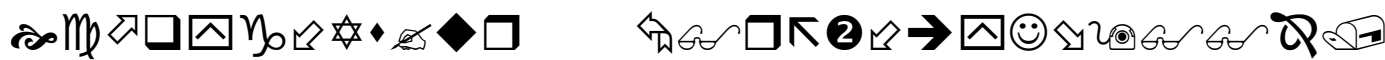

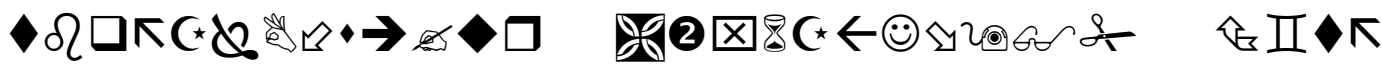

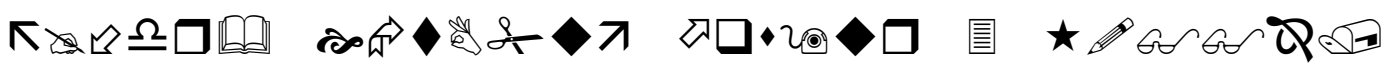
: r m

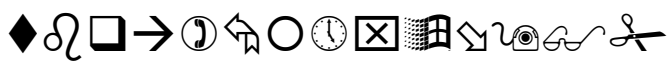

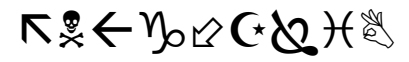

Artinya:

"Kamu adalah umat yang terbaik yang dilahirkan untuk manusia, menyuruh kepada yang ma'ruf, dan mencegah dari yang munkar, dan

\footnotetext{
${ }^{13}$ E-book , Tafsir Jalalain Indonesia. www.zoxcell.com

${ }^{14}$ Al Maraghy, Ahamad Mustafa. Tafsir Al Maraghy. terjemahan: Burhan Abu Bakar dan Herri Noer Ali (Semarang: Toha Putra,1986). HIm. 35
} 
beriman kepada Allah. Sekiranya ahli kitab beriman, tentulah itu lebih baik bagi mereka, di antara mereka ada yang beriman, dan kebanyakan mereka adalah oranq-oranq yanq fasik."

Kata ummah pada ayat tersebut, berasal dari kata amma, ya'ummu yang berarti jalan dan maksud. Dari asal kata tersebut, dapat diketahui bahwa masyarakat adalah kumpulan perorangan yang memiliki keyakinan dan tujuan yang sama, menghimpun diri secara harmonis dengan maksud dan tujuan bersama.

Selanjutnya dalam Al-Mufradat fi Gharib Al-Qur'an, masyarakat diartikan sebagai semua kelompok yang dihimpun oleh persamaan agama, waktu, tempat baik secara terpaksa maupun kehendak sendiri.Inti dari pendapat- pendapat tersebut, adalah bahwa masyarakat tempat berkumnulnva manusia vana didalamnva terdanat sistem hubuncan, aturan serta pola- pola hubungan dalam memenuhi kebutuhan hidupnya. ${ }^{15}$

Ayat tersebut menerangkan dari masyarakat yang mempunyai kesadaran etis sehingga mempunyai tanggung jawab yang tinggi terhadap berlakunya nilai-nilai peradaban yang bersumber dari ajaran agama. Masyarakat etis seperti yang dimaksudkan oleh al-Qur'an, sudah pernah diwujudkan oleh Nabi Muhammad SAW selama sepuluh tahun di Madinah.Nabi berhasil membangun masyarakat yang adil, terbuka, demokratis dencan landasan taqwa kepada Allah SWT dan taat pada ajaran-ajaranNya. ${ }^{16}$

4. Q.S Al-Anfal: 53

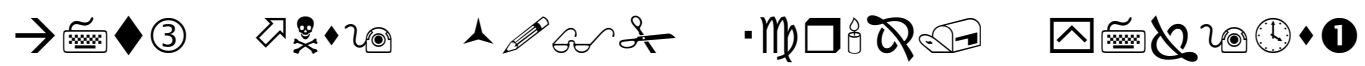

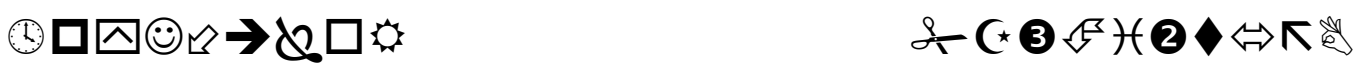

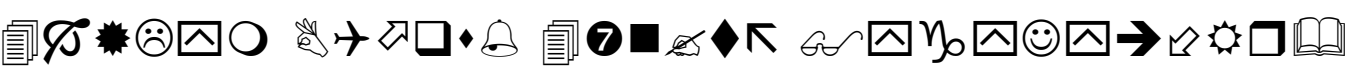
- 邓8 सि Q中: Artinya:

53. (siksaan) yang demikian itu adalah karena Sesungguhnya Allah sekali-kali tidak akan merubah sesuatu nikmat yang telah dianugerahkan-Nya kepada suatu kaum, hingga kaum itu meubah apa-

\footnotetext{
${ }^{15}$ /bid. HIm. 37

${ }^{16}$ Umari, Akram Dhiyauddin, Masyarakat Madani Tinjauan Historis Zaman Nabi, (Jakarta: Gema Insani Press, 1999). HIm. 68
} 
apa yang ada pada diri mereka sendiri[621], dan Sesungguhnya Allah Maha mendengar lagi Maha mengetahui.

Dalam ayat ini Allah ingin menegaskan bahwa Dia tidak akan merubah nikmat suatu kaum, sehingga kaum itu merubah apa yang ada pada diri mereka sendiri. Selain itu kenikmatan yang diterima oleh suatu kaum ataupun perorangan juga tergantung kepada akhlak dan amal mereka itu sendiri. ${ }^{17}$

Sesungguhnya Allah sekali-kali tidak akan mengubah suatu nikmat sedikit atau besar yang telah dianugerahnya kepada suatu kaum, tidak juga sebaliknya mengubah kesengsaraan yang dialami oleh suatu kaum menjadi kebahagiaan hingga kaum itu sendiri terlebih dahulu mengubah apa yang ada pada diri mereka sendiri, yakni untuk memperoleh nikmat tambahan mereka harus lebih baik, sedangkan perolehan siksaan adalah akibat mengubah fitrah kesucian mereka menjadi keburukan dan kedurhakaan dan sesunaduhnva Allah Maha mendenaar ananun vana disuarakan mahkluk lagi maha mengetahui apapun sikap dan tingkah laku mereka. ${ }^{18}$

\section{Masyarakat dalam Pandangan Hadits}

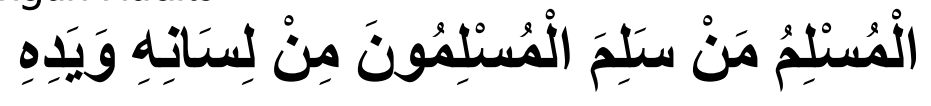

Artinya:

"seorang muslim, yang muslim lainnya selamat dari lisannya dan tangannya". (HR. Muslim).

"Demi yang jiwaku ada di tangan-Nya, seandainya kalian tidak ada yang berdosa, Allah akan gantikan kalian dengan kaum yang berdosa, lalu mereka bersitghar kepada Allah kemudian Allah mengampuni mereka." (HR. Muslim, Shahih Muslim No. 7141). ${ }^{19}$

"Perumpamaan orang yang teguh menjalankan ajaran Allah dan tidak melanggar ajaran-ajaran-Nya dengan orang yang terjerumus dalam perbuatan melanggar ajaran Allah, adalah bagaikan satu kaum yang melakukan undian dalam kapal laut.Sebagian mendapat jatah di atas dan sebagian lagi mendapat jatah di bawah.Penumpang yang berada di bawah, jika mereka hendak mengambil air, mereka harus melewati penumpang yang berada di atas.Lalu mereka berkata, "Seandainya kita lobangi saja kapal ini, maka kita dapat mengambil air tanpa mengganggu penumpang di atas. Jika perbuatan mereka itu mereka biarkan, maka semuanya akan binasa. Namun jika mereka

\footnotetext{
${ }^{17}$ Departemen Agama Republik Indonesia, al Quran dan tafsirnya, juz V. HIm. 19

${ }^{18}$ Shihab, M. Quraish. Tafsir al Mishbah. (Jakarta: Lentera Hati: 2002). HIm. 254

${ }^{19}$ E-book, Ensiklopedia Hadits 9 Imam, shahih Muslim.www.zoxcell.com
} 
mencegahnya, maka semuanya akan selamat."(Shahih Bukhari, no. 2493).

Islam mengajarkan umatnya untuk hidup membaur di tengah msyarakatnya dan sabar menghadapi berbagai konseksenwensi yang harus ditanggungnya.

Rasulullalh saw bersabda:

"Seorang mu'min yang bergaul di tengah masyarakatnya dan sabar terhadap gangguan mereka, lebih baik dari mu'min yang tidak berbaur dengan masyarakat dan tidak sabar terhadap gangguan mereka. "(HR. Ahmad dan Bihaqi. Dinyatakan shahih oleh Al-Albany dalam Silsilah AlAhadits Ash-Shahihah, no. 939)

Makna dari hadist ini bahwa seorang muslim harus melaksanakan rukun-rukun Islam dan melaksanakan apa yang telah diwajibkan oleh Allah Ta'ala, dan menahan tangan dari dzalim kepada manusia serta menahan dari melanggar batas-batasan Allah Ta'ala. Dari makna ini menunjukkan bahwa umat Islam seluruhnya wajib melakukan itu.Karena tidak ada kebahagiaan, kemuliaan dan kesuksesan kecuali dengan agama Islam. ${ }^{21}$

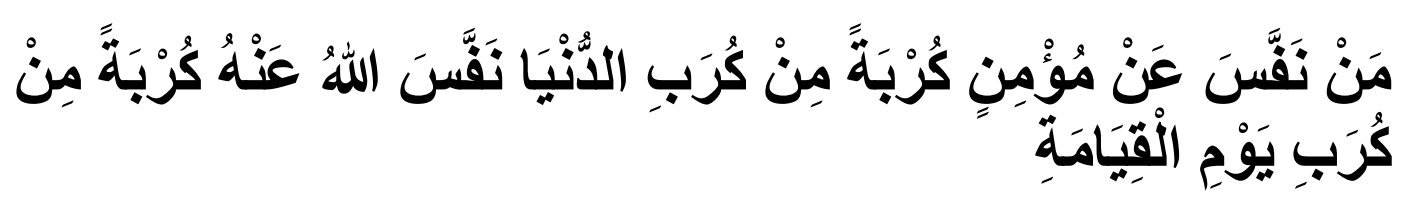

Artinya:

"Barangsiapa melepasakan dari seorang muslim satu kesusahan dari sebagian kesusahan dunia, niscaya Allah akan melepasakan kesusahannya dari sebagian kesusahan hari kiamat" (H.R.Bukhori). ${ }^{22}$

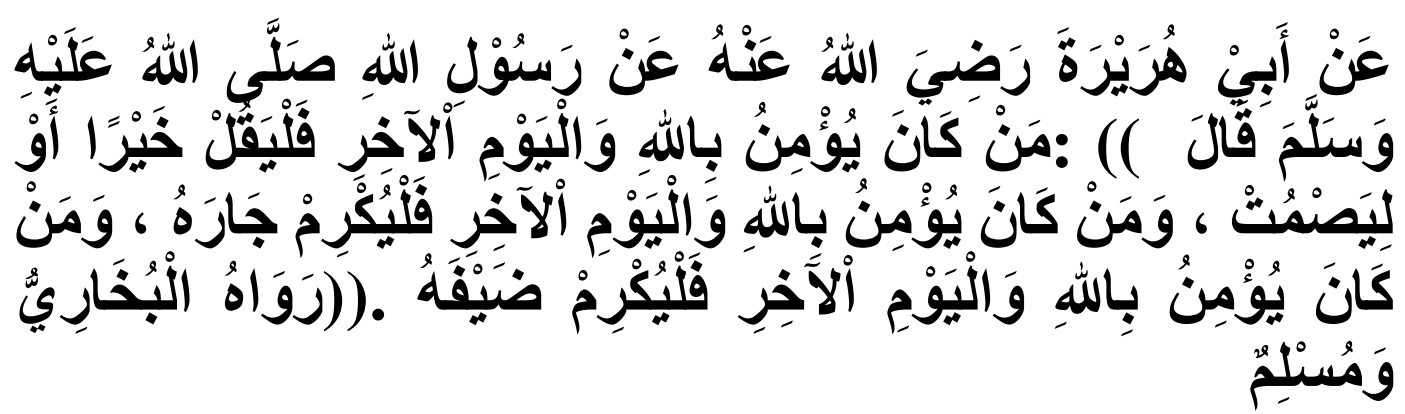

Artinya:

\footnotetext{
${ }^{20}$ E-book, Op.cit.Hlm.2

${ }^{21}$ Baz, Abdullah bin, Syarh Kitab fadhalul Islam, jilid 1, Hlm. 20. Maktabah Syamilah

${ }^{22}$ E-book, Op.cit.HIm. 2
} 
"Dari Abu Hurairah ra. Sesungguhnya Rasulullah saw bersabda: barang siapa yang beriman kepada Allah dan hari akhir maka berkatalah yang baik atau diam, dan barang siapa yang beriman kepada Allah dan hari akhir maka hendaklah ia memuliakan tetangganya, dan barang siapa yang beriman kepada Allah dan hari akhir maka hendaklah ia memuliakan tamunya".(H.R. Bukhori dan Muslim). ${ }^{23}$

Ini merupakan perbuatan iman, sebagaimana yang telah jelas bahwa amal perbuatan termasuk dari iman. "fal yaqul khoiron aw liyasmuth": perintah untuk berkata baik dan diam dari perkataan yang tidak baik atau sia-sia. Jadi adakalanya perkataan itu baik sehingga diperintahkan diucapkan.Dan adakalanya perkataan itu tidak baik dan sia-sia sehingga diperintahkan untuk diam darinya.

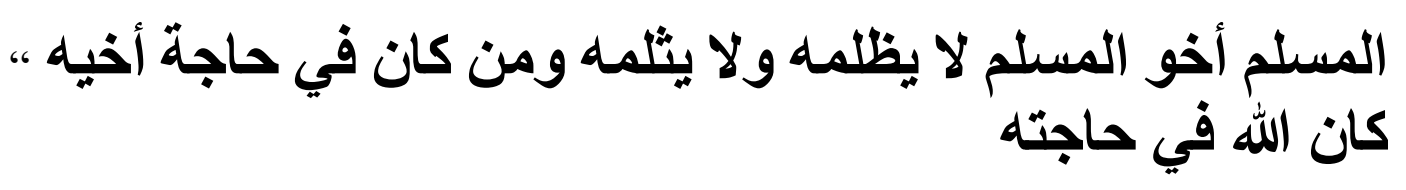

Artinya:

"Seorang muslim itu saudara muslim yang lain, tidak boleh menzhaliminya, membiarkannya (tidak memberikan pertolongan kepadanya) barang siapa yang memenuhi hajat saudaranya, maka Allah akan memenuhi kebutuhannya." (H.R. Thabrani dari kaab bin Ajrah).

\section{Pandangan Filosof Tentang Masyarakat}

Berikut ini adalah pandangan tentang masyarakat menurut beberapa filosof :

1. Al-Farabi mengklarifikasikan masyarakat ke dalam dua golongan, yakni:

a. Masyarakat Sempurna (al-Mujtami' al-Kamilah).adalah masyarakat yang mengandung keseimbangan di antara unsur-unsurnya. Perbedaan hanyalah kalau unsur-unsur masyarakat itu mempunyai kebebasan individual yang lebih besar, maka dalam diri manusia unsur-unsurnya itu lebih dikuasai dan diperintah oleh pusatanya ${ }^{24}$ Selanjutnya, masyarakat yang sempurna, diklasifikasikan menjadi tiga bahagian, pertama masyarakat sempurna besar (gabungan banyak bangsa yang sepakat untuk bergabung dan saling membantu serta bekerjasama, biasa disebut perserikatan bangsa-bangsa), kedua masyarakat sempurna sedang (masyarakat yang terdiri atas suatu

\footnotetext{
${ }^{23}$ Ibid

${ }^{24}$ Poerwantana, dkk, Seluk beluk Filsafat Islam, (Bandung: Rosdakarya, 1988) Cet. Ke-. HIm.138
} 
bangsa yang menghuni di satu wilayah dari bumi biasa disebut negara nasional), ketiga masyarakat sempurna kecil (masyarakat yang terdiri atas para penghuni satu kota (negara kota). ${ }^{25}$

b. Masyarakat tidak/belum sempurna (al-Mujatami' laisa Kamilah), adalah masyarakat yang kehidupannya kecil seperti masyarakat yang penghidupan sosialnya di tingkat desa, kampung, lorong/dusun, dan keluarga. Dalam hal ini, yang kehidupan masyarakat masih jauh dari ketidak sempurnaan adalah keluarga. ${ }^{26}$

2. Peter L. Berger

Masyarakat adalah suatu keseluruhan kompleks hubungan manusia yang luas sifatnya.Keseluruhan yang kompleks sendiri berarti bahwa keseluruhan itu terdiri atas bagian-bagian yang membentuk suatu kesatuan.

Dalam tanggapan ini berarti sebuah aktifitas kreatifitas dari bermacam individu yang tidak dibatasi oleh sifat dari kekreatifannya tersebut akan tetapi masih menjunjung nilai kesatuan dan tetap menghargai perbedaan yang muncul dari individu lain dalam wilayah hubungan tersebut.

3. Koentjaraningrat

Masyarakat adalah orang-orang yang hidup dan menghasilkan kebudayaan sekalipun menerabas tatanan yang ada karena dipengaruhi iklim pembangunan yang berimbas pada mental orang tersebut. ${ }^{27}$

Menurut pendapat ini masyarakat adalah sebuah kelompok yang menghasilkan kebudayaan baik kebudayaan tersebut karena perpaduan dari berbagai produk budaya yang ada maupun sekelompok orang tersebut menciptakan produk budaya murni tanpa adanya sisipan / pengaruh dari budaya lain.

\section{Teori-teori Pembentukan Masyarakat Menurut Para Ahli Filsafat}

\section{Teori Ashabiyah}

25 Sjadzali, Munawir, Islam dan Tata Negara: ajaran, sejarah dan pemikiran, (Jakarta: UI Perss, 1993). HIm. 51-52

${ }^{26}$ Poerwantana dkk, Op.cit.Hlm.138

${ }^{27}$ Koentjaraningrat, Kebudayaan Mentalitas dan Pembangunan, (Jakarta, Gramedia Pustaka Utama, 1994). HIm. 20 
Teori ashabiyah, yang dalam bahasa Inggris disebut dengan "Group Feeling" (rasa satu kelompok) atau lebih tepatnya solidaritas kelompok.Rahman Zainuddin mengatakan bahwa solidaritas adalah kerjasama dan tolong menolong yang erat dalam suatu kelompok manusia dalam bentuk sedemikian rupa sehingga anggota kelompok solidaritas itu bersedia mengorbankan jiwa raganya untuk kepentingan kelompok itu serta para anggotanya.

Dalam teorinya ini, Ibnu Khaldun mengemukakan dua pendapat. Pada pendapat pertama, ia berpendapat bahwa orang tidak mungkin mampu menciptakan sebuah negara tanpa didukung oleh suatu rasa persatuan dan solidaritas yang tinggi. Seperti yang telah dikatakan dalam muqaddimahnya: "(mendominasi dan mempertahankan diri hanya dapat dilakukan dengan solidaritas, karena didalamnya terdapat ajakan untuk waspada, kesiagaan untuk berperang dan kesediaan orang dalam kelompokitu untuk mengorbankan jiwa dalam mempertahankan temannya). 28

Pada pendapat kedua, Ibnu Khaldun berpendapat bahwa dalam mendirikan sebuah negara dibutuhkan suatu kerja keras dan perjuangan yang hebat, yakni pertarungan hidup dan mati.Sebab kekuasaan negara adalah suatu bangunan yang kokoh yang tidak dapat dirobohkan siapa saja.Untuk itu diperlukan kekuatan yang besar. ${ }^{29}$

\section{Teori Atomistic}

Pada periode masyarakat sebelum terbentuknya negara seperti yang kita kenal sekarang (pre social state) manusia sebagai pribadi adalah bebas dan independen.Dengan demikian masyarakat dibentuk atas dasar kehendak bersama, untuk tujuan bersama para individu, yang kemudian menjadi warga masyarakat itu. ${ }^{30}$

Pribadi manusia sebagai individu memiliki kebebasan, kemerdekaan dan persamaan diantara manusia lainnya.Karena didorong oleh kesadaran tertentu, mereka secara sukarela membentuk masyarakat, dan masyarakat dalam bentuknya yang formal ialah negara.Oleh sebab itu masyarakat adalah perwujudan kontrak sosial, perjanjian bersama warga masyarakat itu.Berdasarkan asas pandangan atomisme ini penghargaan kepada pribadi

${ }^{28}$ http://carapedia.com/pengertian_definisi_masyarakat_menurut_para_ahli_info488 .$h t m l$

\footnotetext{
${ }^{29}$ http: Ibid

${ }^{30}$ http: Ibid
} 
manusia adalah prinsip utama.Artinya setiap praktek tentang kehidupan di dalam masyarakat selalu diarahkan bagi pembianaan hak-hak asasi manusia, demi martabat manusia.

\section{Teori Organisme}

Pada dasarnya setiap individu dilahirkan dan berkembang di dalam masyarakat. Manusia lahir dalam wujud yang serba lemah, lahir dan bathin. Keadaannya dan perkembangannya amat tergantung (dependent) kepada orang lain, minimal kepada keluarganya. Kenyataan ini tidak hanya pada masa bayi dan masa kanak-kanak, bahkan di dalam perkembangan menuju kedewasaan seseorang individu masih memerlukan bantuan orang lain. Misalnya dalam penyesuaian kelangsungan hidupnya.Oleh karena itu manusia saling membutuhkan sesamanya demi kelanjutan hidup dan kesejahteraannya. ${ }^{31}$

\section{Teori Integralistik}

Menurut teori ini meskipun masyarakat sebagai satu lembaga yang mencerminkan kebersamaan sebagai satu totalitas, namun tidak dapat diingkari realita manusia sebagai pribadi.Sebaliknya manusia sebagai pribadi selalu ada dan hidup di dalam kebersamaan di dalam masyarakat.Jelas bahwa pribadi manusia adalah suatu realita di dalam masyarakat, seperti halnya masyarakat pun adalah realita diantara bangsa bangsa di dunia ini dan komplementatif.Masyarakat ada karena terdiri dari pada individu-individu warga masyarakat.Dan pribadi manusia, individuindividu dalam masyarakat itu berkembang dan dipengaruhi oleh masyarakat. $^{32}$

\section{Prinsip-prinsip yang Menjadi Dasar Pandangan Islam tentang Masyarakat}

Islam punya pandangannya yang tersendiri tentang masyarakat dan kehidupan. Beberapa prinsip yang menjadi dasar pandangan Islam tentang masyarakat ialah: ${ }^{33}$

\section{a. Prinsip Pertama}

Mengakui bahwa masyarakat dalam pengertian yang paling sederhana ialah kumpulan individu dan kelompok yang diikat oleh kesatuan negara, kebudayaan dan agama.Termasuk segala jalinan yang timbal balik, berkepentingan bersama, adat kebiasaan, pola-pola, teknik-

\footnotetext{
${ }^{31}$ http: Ibid

${ }^{32}$ http: Ibid

${ }^{33}$ Al-Toumy Op.cit. HIm. 164
} 
teknik, sistem hidup, undang-undang, institusi dan segala segi dan fenomena yang dirangkum masyarakat dalam pengertian luas. ${ }^{34}$

\section{b. Prinsip Kedua}

Menyakini bahwa masyarakat Islam mempunyai sikap dan cirinya tersendiri, membedakan dari masyarakat lain. Menyebabkan masyarakat Islam benar-benar menjadi masyarakat ideal yang menjadi contoh masyarakat lain untuk menikmati kebahagiaan, kemakmuran dan memenuhi kebutuhan jasmani dan rohani. Masyarakat yang digariskan Islam hendaknya dibina dengan moral atau nialai-nilai islam yang berlandaskan pada al-Qur'an dan hadist. ${ }^{35}$

\section{c. Prinsip Ketiga}

Masyarakat Islam menyakini bahwa azas untuk membina masyarakat ialah akidah kepercayaan bahwa Allah itu Esa, serta menyakini rukun-rukun iman lainnya dan rukun-rukun Islam.Masyarakat Islam adalah masyarakat tauhid karena masyarakat Islam adalah merupakan wujud atas tegaknya pondasi iman.Islam merobohkan syirik sosial.Tauhid menyatukan orangorang yang menerimanya dalam satu ikatan yang menyamaratakan hak dan tanggung jawab masing-masing pada dasarnya.Tidak ada Tuhan selain Allah (QS. Muhammad 47: 19). Jika kamu mencintai Allah, ikutilah aku, niscaya Allah mencintaimu (QS. Ali 'Imran 3: 31). ${ }^{36}$

\section{d. Prinsip Keempat}

Meyakini bahwa agama dalam pengertian luas yang merangkum setiap yang berhubungan dengan akidah, ibadah, pergaulan, antara sesama manusia ialah merupakan teras dalam kehidupan pribadi dan masyarakat.Agama diletakkan pada proporsi yang tertinggi.Segala urusan hidup dikembalikan kepada hukum hakamnya sesuai dengan ayat alQur'an yang menyeru supaya pertikaian dikembalikan kepada putusan Allah dan Rasul.Artinya merujuk prinsip dan dasar yang dikandung oleh ajaran Allah dan Rasul.Jika berbeda pendapat tentang sesuatu, maka hendaklah dikembalikan kepada Allah dan Rasul-Nya (QS.An-Nisa' 4: 59). ${ }^{37}$

\section{e. Prinsip Kelima}

Masyarakat Islam menyakini bahwa ilmu yang yang sebenarbenarnya dan sebaik-baiknya adalah iman dan akhlak untuk mencapai

\footnotetext{
${ }^{34}$ Al-Toumy Ibid.

${ }^{35}$ Al-Toumy Ibid. HIm. 167

${ }^{36}$ Al-Toumy Ibid. HIm. 178

${ }^{37}$ Al-Toumy Ibid. HIm. 182
} 
kemajuan, kemakmuran dan kekuatan masyarakat Islam.Masyarakat Islam adalah masyarakat berilmu. Ilmu yang benar adalah sebaik cara untuk memantapkan akidah dan agama. Ilmu adalah salah satu persyaratan dalam pelaksanaan tugas khalifah di bumi. Tidak sepatutnya semua mukmin pergi ke medan perang, mengapa sebagian tidak pergi untuk memperdalam pengetahuan agama (QS. al-Taubah 9:122), dan pengajaran Allah kepada nabi-Nya untuk berdo'a: "Ya Tuhanku, tambahkanlah ilmu kepadaku." (QS. Thaha; 20: 114). ${ }^{38}$

\section{f. Prinsip Keenam}

Masyarakat Islam selalu mengikuti perubahan dan kemajuan zaman melalui struktur masyarakat sistem kebudayaan dan kemajuan ilmu pengetahuan dan teknologi yang selalu diselaraskan dengan nilai-nilai islami. Masyarakat Islam adalah masyarakat yang terbuka, bisa menerima pengaruh baik dari masyarakat lain atau pengaruh ilmu pengetahuannya. Namun dalam proses interaksi tidak sampai kehilangan identitas Islamnya yang unik. Masyarakat Islam adalah masyarakat yang dinamik. Allah tidak akan mengubah keadaan suatu kaum sebelum mereka mengubah keadaan diri mereka sendiri (QS. al-Ra'du 13: 11) , dan lihat (QS. al-Anfal 8: 53). ${ }^{39}$

\section{g. Prinsip Ketujuh}

Meyakini pada pentingnya individu dalam masyarakat.Masyarakat Islam menghormati dan menjaga kehormatan manusia.Tidak bersikap terpisah karena warna, bangsa, agama, harta atau keturunan.Hak untuk hidup aman, bebas, membina keluarga dan memelihara anak. ${ }^{40}$

\section{h. Prinsip Kedelapan}

Meyakini pada pentingya keluarga dalam masyarakat.Masyarakat Islam berusaha untuk menguatkan ikatan dan binaan institusi keluarga.Wanita dipandang sebagai benteng yang mempertahankan masyarakat dan keluarga.Hubungan kekeluargaan dibina atas tunas-tunas yang luhur, kebenaran, keadilan, dan kasih sayang.Allah menciptakan pasangan-pasangan untukmu, agar kamu merasa tentram dan menjadikan di antaramu rasa kasih sayang (QS. al-Rum 30: 21). ${ }^{41}$

\section{i. Prinsip Kesembilan}

\footnotetext{
${ }^{38}$ Al-Toumy Ibid. HIm. 188

${ }^{39}$ Al-Toumy Ibid. HIm. 195

${ }^{40}$ Al-Toumy Ibid. HIm. 198

${ }^{41}$ Al-Toumy Ibid. HIm. 204
} 
Meyakini bahwa segala yang menuju kesejahteraan bersama, keadilan dan kemaslahatan antara manusia termasuk diantaranya tujuantujuan syari'at Islamiyah. ${ }^{42}$

Jadi, setelah membaca dan menelaah pandangan Islam terhdapat masyarakat.penulis mengambil kesimpulan yaitu : bahwa masyarakat Islam selalu bekerjasama, saling tolong menolong, beradaptasi, berpartisipasi dalam kehidupanya sehari-hari. Masyarakat Islam selalu mengambil semua aspek kehidupan serta mengembalikan hukum kepada sumber hukum Islam yang hakiki yaitu kalamullah (al-Qur'an) dan al-Hadits sebagai sumber hukum dikehidupannya. Masyarakat Islam selalu berinovasi dan mengembangkan ilmu pengetahuan dan teknologi untuk memajukan dan memakmuran masyarakat Islam yang memfilteri segala sesuatu dengan nilai-nilai Islam. Dengan adanya kemajuan ilmu pengetahuan teknologi untuk membuat masyarakat Islam lebih berpendidikan dan lebih jenius serta selalu membawa nilai-nilai Islam dikehidupanya sehari-hari.

\section{Implikasi Kajian Tentang Masyarakat Terhadap Pendidikan Islam}

Menurut Al-Syaibani, di samping masyarakat merupakan arena tempat berlangsungnya proses pendidikan, masyarakat itu sendiri juga merupakan satu faktor pokok yang mempengaruhi pendidikan. $^{43}$ Masyarakat dan pendidikan merupakan dua komponen yang tidak dapat dipisahkan satu sama lainnya, masyarakat membutuhkan pendidikan begitu pula sebaliknya, tanpa masyarakat pendidikan tidak akan berjalan dengan baik karena di dalam pendidikan terdapat unsur masyarakat seperti guru, peserta didik dan lain-nya, begitu pula sebaliknya tanpa ada pendidikan masyarakat akan menjadi bodoh dan tidak mempunyai ilmu pengetahuan.

Selain itu masyarakat juga dipandang sebagai "laboratorium dimana anak belajar, menyelidiki dan turut serta dalam usaha-usaha masyarakat yang mengandung unsur masyarakat". ${ }^{44}$ Dan masyarakat berfungsi sebagai "penerus budaya dari generasi selanjutnya secara dinamis sesuai situasi dan kondisi serta kebutuhan masyarakat melalui pendidikan dan interaksi sosial". ${ }^{45}$ Yang sehingga sangat mustahil bila kedua unsur ini yakni

\footnotetext{
${ }^{42}$ Al-Toumy Ibid. HIm. 229

${ }^{43}$ Al-Toumy Ibid.HIm. 164

${ }^{44}$ Abu Ahmadi. Op.cit. Hlm. 133

${ }^{45}$ Ary H. Gunawan, Sosiologi Pendidikan, suatu analisis sosiologi tentang berbagai problem pendidikan, ( Jakatra: Rineka Cipta, 2000). HIm. 54
} 
pendidikan dan masyarakat dipisah dan tidak berkaitan dan apabila kedua hal tersebut tidak menyatu maka akan menghasilkan hasil didikan yang tidak sesuai dengan kebutuhan masyarakat dan lingkungan.

Dan pendidikan juga harus memenuhi kebutuhan dari pada masyarakat itu sendiri sehingga kelak terbentuklah masyarakat yang madani yang dimana kemudian dalam Undang-Undang negara Indonesia juga telah dirumuskan tentang pendidikan yang mengikuti atas kebutuhan masyarakat sekitar, yang termaktub dalam Undang-Undang No. 20 tahun 2003.

Kemudian al-Quran juga menyeru agar kita mempersiapkan generasi-generasi tangguh.sebagaimana yang terdapat pada surat An-Nisa ayat 9 yaitu:

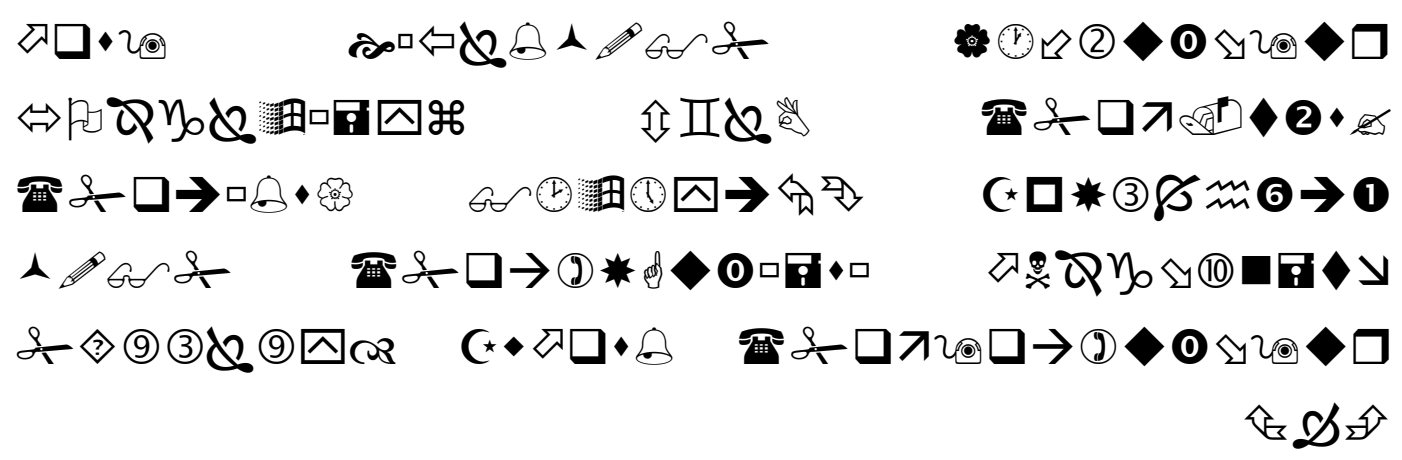

Artinya:

"Dan hendaklah takut kepada Allah orang-orang yang seandainya meninggalkan dibelakang mereka anak-anak yang lemah, yang mereka khawatir terhadap (kesejahteraan) mereka.oleh sebab itu hendaklah mereka bertakwa kepada Allah dan hendaklah mereka mengucapkan Perkataan yang benar".

Ayat diatas merupakan perintah agar umat Islam mempersiapkan generasi yang kuat, yang dimulai dari unit terkecil yaitu keluarganya. Demikian juga bila dibawa kepada lingkup yang lebih luas yaitu lingkup masyarakat, dimana masyarakat harus memiliki solidaritas yang tinggi terhadap sesama sehingga proses pendidikan berjalan dengan baik dan lancar. Dimana "semua anggota masyarakat memikul tanggung jawab membina, memakmurkan, memperbaiki, dan memerintahkan yang ma'ruf melarang yang mungkar". ${ }^{46}$

\section{Kesimpulan}

\footnotetext{
${ }^{46}$ Al Muna Baqy. Op.cit. HIm. 30
} 
Secara mudah kita dapat artikan masyarakat sekumpulan manusia yang berinteraksi dalam suatu hubungan sosial. Masyarakat terdiri atas kelompok-kelompok manusia yang saling terkait oleh sistem-sistem, adat istiadat, serta hukum-hukum khas, dan yang hidup bersama. Kehidupan bersama ialah kehidupan yang di dalamnya kelompok-kelompok manusia hidup bersama-sama di suatu wilayah tertentu dan sama-sama berbagi iklim serta makanan yang sama.

Manusia itu bersifat kemasyarakatan, artinya bahwa secara fitrah, ia bersifat kemasyarakatan. Di satu pihak, kebutuhan, keuntungan, kepuasan, karya dan kegiatan manusia, pada hakikatnya bersifat kemasyarakatan, dan sistem kemasyarakatannya tetap ada selama ada pembagian kerja atau aturan, dan rasa saling membutuhkan dalam suatu perangkat tertentu, tradisi dan sistem. Di pihak lain, gagasan-gagasan, ideal-ideal, perangaiperangai serta kebiasaan-kebiasaan khas manguasai manusia umumnya, dengan memberi mereka satu rasa kesatuan. Bila dihubungkan semua ini dengan pendidikan, maka segala pengalaman yang berlangsung dalam lingkungan dan sepanjang hidup bersama, dengan berbagai keterikatannya itu, dapat dikatakan pendidikan kemasyarakatan.

Beberapa ciri masyarakat Islam di atas adalah merupakan tujuan yang harus dicapai melalui penjelmaan nilai-nilai yang mengatur masyarakat Islam, yang telah dilestarikan oleh al-Qur'an, sebagaimana tercantum dalam surat Ali Imran 3: 104 dan 130, surat al-Hasyar 59: 9, alJum'ah 62: 10, dan lain-lainnya, yaitu kesejahteraan (kebahagiaan) yang dengan jelas dikaitkan dengan masyarakat maupun individu (QS. al-A'la 87: 14), kemudian menuju kesejahteraan kolektif (bersama) yang disajikan dalam semua dimensi. Ada beberapa kata yang disebutkan Allah dalam alQur'an yang merujuk kepada masyarakat, sebagaimana tercantum dalam surah al-Baqarah: 213, surah Ali Imran: 104, 110.

\section{Daftar Pustaka}

Abu Ahmadi. Sosiologi Pendidikan, Jakarta: Rineka Cipta. 2004.

Al Maraghy, Ahamad Mustafa. Tafsir Al Maraghy. terjemahan: Burhan Abu Bakar dan Herri Noer Ali, Semarang: Toha Putra,1986.

Al Muna Baqy, Abdul Fuad Muhammad. Al-Mu'jam Li al-fazhi al-Qur'an alKarim, Mesir: Daar al Kitab, 1945.

Al Munawwir, Ahmad Warson. Al Munawwir Kamus Arab-Indonesia, Surabaya: Pustaka Progresif, 1984. 
Al-Toumy Al-Syaibani, Omar Mohammad, Falsafah Pendidikan Islam, Jakarta: Bulan Bintang, 1979)

H. Gunawan Ary, Sosiologi Pendidikan, suatu analisis sosiologi tentang berbagai problem pendidikan, Jakatra: Rineka Cipta, 2000.

Abdullah bin Baz, Syrah Kitab Fadhalul Islam, Jilid 1, Maktabah Syamilah

Chaniago, Amran YS. Kamus Lengkap Bahasa Indonesia, Bandung: Pustaka Setia, 2002.

Durkheim, Emil, The Elementary Forms of the Religious Life (trans, Joseph Ward Swaim), New York: Macmillan Company, 1915.

E-book , tafsir fi zhilalil qur'an I,

E-book, Tafsir Jalalain Indonesia. www.zoxcell.com

H. Kaelan, Pendidikan Pancasila edisi enam, Yogyakarta : Paradigma, 2002.

http://carapedia.com/pengertian_definisi_masyarakat_menurut_para_ahli_in fo488.htm/

M. Katsir Ibrahim, Kamus Arab Indonesia -Indonesia Arab, Surabaya: Apollo, t.th.

Koentjaraningrat, Kebudayaan Mentalitas dan Pembangunan, Jakarta, Gramedia Pustaka Utama, 1994.

Murtadha Muthahhari, Masyarakat Dan Sejarah, terjemahan: M.Hashem, judul asli: Society and History, Bandung: Mizan, 1992.

Poerwantana, dkk, Seluk beluk Filsafat Islam, Bandung: Rosdakarya, Cet. Ke$1,1988$.

Yusuf Qordhawi, Masyarakat Berbasis Syariat Islam. terj. Abdus Salam Masykur, Solo: Intermedia, 2003.

M. Quraish Shihab, Tafsir al Mishbah, Jakarta: Lentera Hati: 2002.

Sidi Gazalba, Masyarakat Islam Pengantar Sosiologi dan Sosiografi, Jakarta: Bulan Bintang, 1976.

Munawir Sjadzali, Islam dan Tata Negara; ajaran, sejarah dan pemikiran, Jakarta: UI Perss, 1993.

Tim Penyusun, Kamus Besar Bahasa Indonesia, Edisi ketiga, Jakarta: Balai Pustaka, 2005.

Tim Penyusun, Departemen Agama Republik Indonesia, al Quran dan Tafsirnya, juz IV.

Akram Dhiyauddin Umari, Masyarakat Madani Tinjauan Historis Zaman Nabi, Jakarta: Gema Insani Press, 1999. 